\title{
SISTEM INFORMASI MONITORING TUGAS AKHIR (SIMTA) BERBASIS WEB FAKULTAS MIPA UNIVERSITAS TANJUNGPURA
}

\author{
Neva Satyahadewi ${ }^{1}$, Nurul Mutiah ${ }^{2}$ \\ ${ }^{1}$ Jurusan Matematika-Fakultas Matematika dan Ilmu Pengetahuan Alam, Universitas Tanjungpura \\ ${ }^{2}$ Jurusan Sistem Informasi-Fakultas Matematika dan IImu Pengetahuan Alam, Universitas Tanjungpura \\ Jalan Prof. Hadari Nawawi, Pontianak-Kalimantan Barat - 78124 \\ ${ }^{1}$ neva.satya@math.untan.ac.id, ${ }^{2}$ nurulmutiah.1811@gmail.com
}

\begin{abstract}
Abstrak-Sistem Informasi merupakan komponen penting dalam teknologi penyampaian informasi yang ada pada suatu instansi. Penelitian berfokus mulai pada perancangan dan pembuatan roadmap Sistem Informasi FMIPA Universitas Tanjungpura, pembuatan Sistem Informasi Tugas Akhir (SIMTA) sebagai dasar pengelolaan operasional infomasi tugas akhir di FMIPA Universitas Tanjungpura serta. Hal ini bertujuan agar aktivitas mahasiswa dari kegiatan tersebut dapat terpantau dan dikelola dengan tepat dan akurat oleh FMIPA Universitas Tanjungpura. Salah satu fitur yang dibangun yaitu, dapat memonitoring mahasiswa yang 6 bulan atau 1 tahun sudah tidak bimbingan sehingga dapat diberikan peringatan melalui sms maupun notifikasi. Hasilnya adalah aplikasi Sistem Informasi Tugas Akhir (SIMTA) dapat diterapkan di perguruan tinggi FMIPA Universitas Tanjungpura khususnya di tingkat prodi maupun akademik Fakultas. Adapun pengguna dari aplikasi ini ditujukan kepada dosen, staf maupun mahasiswa FMIPA Universitas Tanjungpura..
\end{abstract}

Kata Kunci-SIMTA, Sistem Informasi, Tugas Akhir, Teknologi Informasi

\section{PENDAHULUAN}

Kemajuan teknologi informasi telah menyentuh ke berbagai bidang kehidupan seperti bidang ekonomi, kesehatan, keamanan, dan tak terkecuali di bidang pendidikan, terutama pendidikan tinggi. Pada praktiknya, hampir bisa ditemui di banyak perguruan tinggi implementasi Sistem Informasi Manajemen (SIM) bisa didapati dengan berbagai bentuk, baik yang sangat sederhana bahkan sampai dengan tingkat kerumitan yang sangat tinggi (Ramadhan, et al., 2017). Sistem informasi pada bidang pendidikan tinggi merupakan kumpulan orang, software, hardware, prosedur, dan aturan yang saling bekerjasama untuk mendorong efektifitas proses pendidikan tinggi.

FMIPA merupakan salah satu fakultas di Universitas Tanjungpura yang memiliki 9 Program Studi yaitu Matematika, Fisika, Kimia, Sistem Informasi, Rekayasa Sistem Komputer, Geofisika, Ilmu Kelautan, Statistika dan Biologi. Pengelolaan manajerial administrasi dan kearsipan belum berjalan dengan maksimal, hal ini dapat terlihat belum adanya suatu pangkalan data digital yang dapat memudahkan para pemangku jabatan untuk melihat kesatuan data dari tiap-tiap aktivitas kegiatan, mulai dari layanan kearsipan surat menyurat, berkas-berkas data pegawai sampai pengelolaan tugas akhir mahasiswa, kerja praktik dan penelitian-penelitian mahasiswa yang pernah dilakukan.

Berdasarkan permasalahan yang sudah dipaparkan dan berkaitan dengan visi FMIPA Universitas Tanjungpura "Pada tahun 2020 Untan menjadi institusi preservasi dan pusat informasi ilmiah Kalimantan Barat serta menghasilkan luaran yang bermoral Pancasila dan mampu berkompetisi baik di tingkat daerah, nasional, regional, maupun internasional ".

Sehingga untuk mendukung visi tersebut, FMIPA Universitas Tanjungpura berusaha menerapkan kemajuan teknologi informasi dan komunikasi untuk mengotomasi proses manajerial-nya. Dengan membangun berbagai sistem informasi yang terhimpun di dalam wadah yang bernama Sistem Informasi Manajemen Pendidikan diharapkan FMIPA Universitas Tanjungpura dapat membuat proses pendidikan tinggi yang berjalan menjadi lebih efektif dan efisien. Penelitian ini akan berfokus pada perancangan dan pembangunan roadmap Sistem Informasi FMIPA Universitas Tanjungpura, pembuatan Sistem Informasi Kearsipan Digital sebagai dasar pengelolaan operasional FMIPA Universitas Tanjungpura, serta pembuatan Sistem Informasi Tugas Akhir, Kerja Praktik dan Penelitian Mahasiswa untuk mempermudah dosen dan mahasiswa didalam pelaksanaan dan pemantauan tugas akhir mahasiswa, sehingga riwayat proses bimbingan dan aktivitas mahasiswa dapat terekam dengan detail, tepat dan akurat.

\section{METODOLOGI PENELITIAN}

Tahapan-tahapan penelitian diperlukan dalam membangun metode penelitian. Sehingga hasil dari penelitian nantinya lebih prosedural dan relevan. Adapun tahapan-tahapan dalam membangun metode penelitian adalah sebagai berikut : 


\section{A. Materi penelitian}

Adapun materi penelitian yang dibutuhkan dalam hal ini menyangkut :

1. Sistem informasi

Menurut Turban dkk (2005) sistem adalah kumpulan objek seperti orang, sumberdaya, konsep dan prosedur

Page | 84 yang dimaksudkan untuk melakukan suatu fungsi yang dapat diidentifikasi atau untuk melayani suatu tujuan. Sistem informasi adalah sistem yang mengumpulkan, memproses, menyimpan, menganalisis, dan menyebarkan informasi untuk suatu tujuan khusus (Turban dkk, 2005: 60). Sistem informasi merupakan suatu solusi atas permasalahan organisasional dan manajerial, dengan memanfaatkan teknologi informasi untuk mengantisipasi tantangan dari lingkungannya.

Mengacu pada Turban dkk (2005) struktur sistem ada 6 macam, yaitu:

1. Input adalah elemen yang masuk ke dalam sistem

2. Proses adalah semua elemen yang diperlukan untuk mengonversi atau mentransformasi input kedalam output,

3. Output adalah produk akhir atau konsekuensi yang ada pada sistem,

4. Umpan balik adalah aliran informasi dari komponen output ke pengambil keputusan berkenaan dengan output atau performa sistem, berdasarkan output, pengambil keputusan dapat memutuskan untuk memodifikasi input, proses, atau keduanya,

5. Lingkungan sistem, terdiri dari beberapa elemen yang ada diluar, dalam hal mereka bukanlah input, output atau proses. Akan tetapi, mereka mempengaruhi performa sistem dan pencapaian tujuan sistem.

6. Batasan, dapat berupa fisik dan non-fisik. Batasan sebuah sistem ditentukan dengan mempersempit lingkup sistem untuk mempermudah analisis.

7. Komponen sistem informasi terdiri dari hardware, programs, data, prosedur, people.

2. Kebutuhan Penelitian

Adapun kebutuhan perangkat yang digunakan dalam Aplikasi Sistem Informasi Tugas Akhir (SIMTA) di Fakultas MIPA Universitas Tanjungpura. Pada penerapannya kebutuhan penelitian terbagi menjadi berikut:

a) Kebutuhan Perangkat Keras
Kebutuhan perangkat keras yang mendukung sebagai sarana penunjang berupa Personal Computer dengan spesifikasi sebagai berikut:

1. SERVER

2. Processor Intel i3/sederajat

3. RAM minimal $4 \mathrm{~GB}$

4. HDD 500GB

b) Kebutuhan Perangkat Lunak

Perangkat lunak (software) yang akan digunakan dalam perancangan dan implementasi sistem adalah sebagai berikut:

1. MySql digunakan sebagai Database.

2. Aplikasi Sublime sebagai program coding.

3. Bahasa pemrograman yang dipakai HTML5+PHP+CSS+Javascript.

4. draw.io digunakan untuk membuat usecase diagram, Activity Diagram, sequence diagram, class diagram, dan mockup interface.

5. Microsoft Word Office digunakan sebagai pembuatan laporan.

\section{B. Rancangan Penelitian}

Prosedur penelitian yang dimaksud ialah proses yang dilakukan selama penelitian hingga akhir.

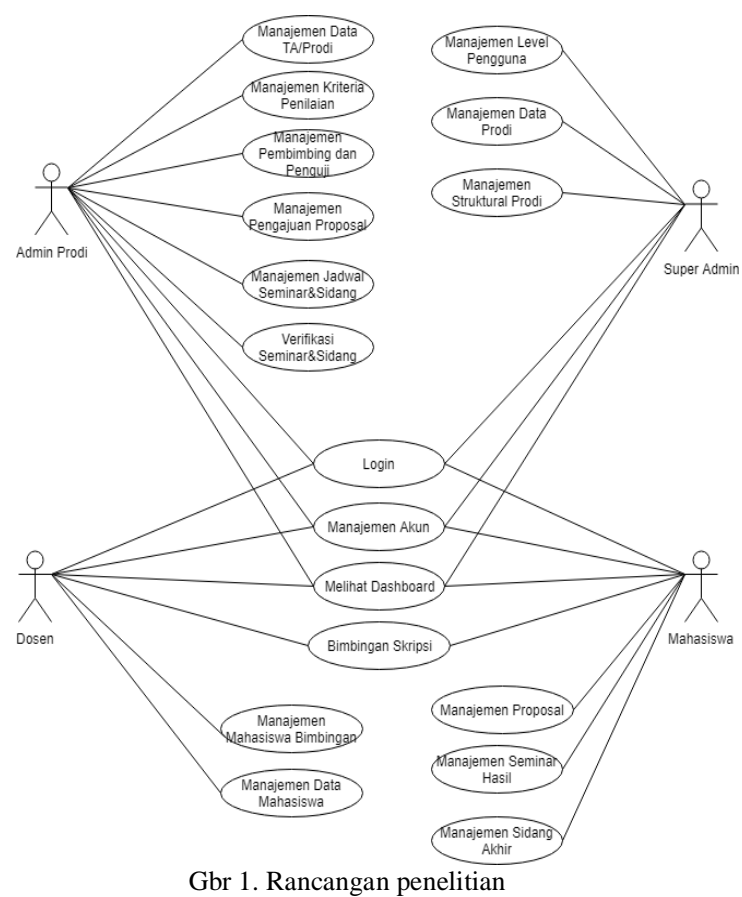

Kebutuhan level User:

- Pendataan User1 (Super Admin) yang melakukan pengelolaan:

a. User1 dapat melakukan login

b. User1 dapat memantau grafik pengguna perkategori (Admin Prodi, Dosen, Mahasiswa), 
memantau jumlah admin, dosen, mahasiswa per prodi, memantau

c. data mahasiswa tahap skripsi \& bimbingan, seminar hasil, sidang perprodi dan memantau data alumni.

d. User1 dapat menambah pengguna sistem pada level admin prodi, dosen dan mahasiswa.

Page | 85

e. User 1 dapat mengelola master pengguna, master data prodi dan struktural prodi.

f. User1 dapat mereset password prodi.

g. User1 dapat melakukan pengaturan akunnya sendiri.

Pendataan User2 (Admin Prodi) yang melakukan pengelolaan:

a. User2 dapat melakukan login

b. User2 dapat memantau grafik mahasiswa prodi yang sedang tugas akhir.

c. User2 dapat mengelola master data prodi, kriteria penilaian, memilih pembimbing/penguji, pengajuan proposal, jadwal dan verifikasi.

d. User2 dapat melakukan pengaturan akunnya sendiri.

- Pendataan User3 (Dosen) yang melakukan pengelolaan:

a. User3 terbagi menjadi tiga yakni dosen biasa, dosen sekertaris prodi dan kepala prodi.

b. User3 dapat melakukan login.

c. User3 dapat melihat grafik mahasiswa bimbingan.

d. User3 dapat memilih pembimbing/penguji.

e. User3 dapat melakukan pengaturan akunnya sendiri.

- Pendataan User4 (Mahasiswa) yang melakukan pengelolaan:

a. User4 dapat melakukan login.

b. User4 dapat mengelola dan melihat data proposal.

c. User4 dapat mengelola dan melihat data Seminar Hasil.

d. User4 dapat mengelola dan melihat data Sidang Akhir.

e. User4 dapat melakukan pengaturan akunnya sendiri.

Activity Diagram Admin Prodi (Dashboard)

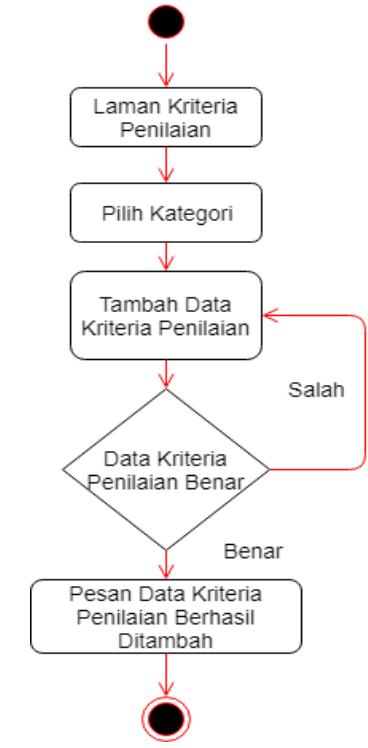

Gbr 2. Activity Diagram Admin Prodi (Kriteria Penilaian)

Pada pengguna admin prodi, memiliki fungsi untuk membuat kriteria penilaian dalam proses seminar proposal, seminar hasil dan sidang sarjana. Ketika dosen melakukan penilaian, maka sistem akan merekam semua aktivitas penilaian di dalam basis data.

\section{HASIL DAN PEMBAHASAN}

\section{A. Antarmuka}

Tampilan ini berisikan pembuatan akun, Username dan password yang harus diisikan sesuai dengan level penggunanya.

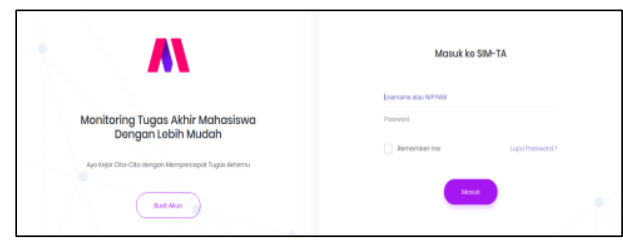

Gbr 3. Antarmuka Tampilan Login

Admin Prodi merupakan User yang bisa mengakses segala aspek dari semua tampilan User lainnya. Mulai dari verifikasi pengajuan, penjadwalan, pemberkasan seminar serta tracer alumni.

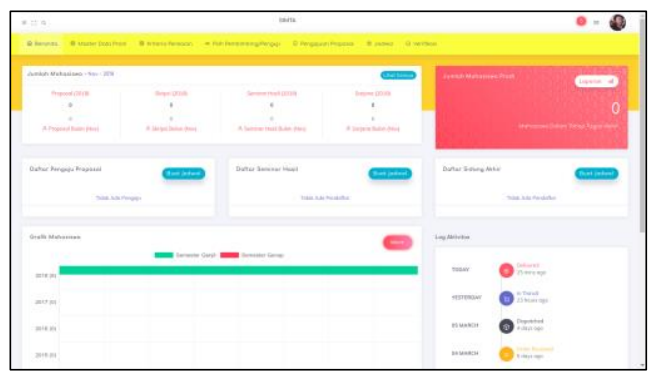

Gbr 4. Antarmuka Admin Prodi (User1) 
Tampilan ini berisikan informasi banyaknya pengajuan proposal, seminar hasil dan sidang tugas akhir.

Page $\mid 86$

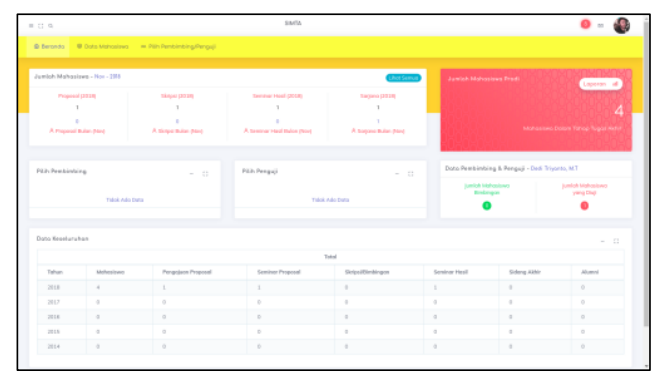

Gbr 5. Antarmuka Kepala Prodi (User2)

Antarmuka ini memiliki fitur atur jadwal untuk mahasiswa melaksanakan Seminar Proposal, Hasil dan Sidang.

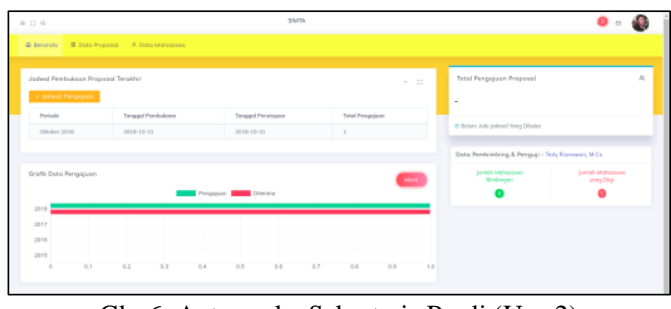

Gbr 6. Antarmuka Sekretaris Prodi (User2)

Tampilan ini berisikan informasi seputar grafik perkembangan tugas akhir mahasiswa dan beserta dosen pembimbing dan pengujinya..

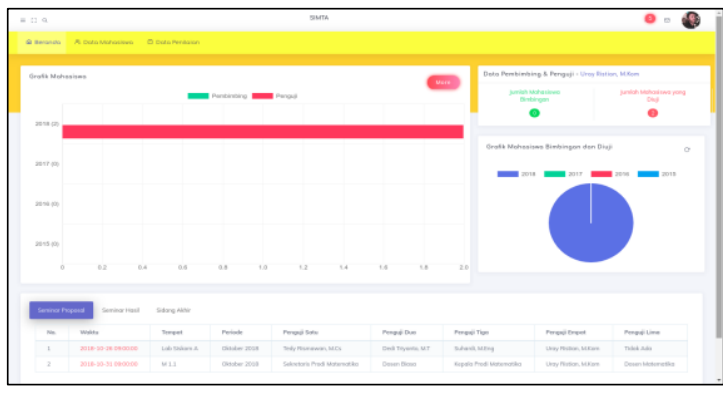

Gbr 7. Antarmuka Dosen (User3)

Tampilan ini berisikan informasi seputar aktifitas bimbingan tugas akhir mahasiswa dengan dosen pembimbing.

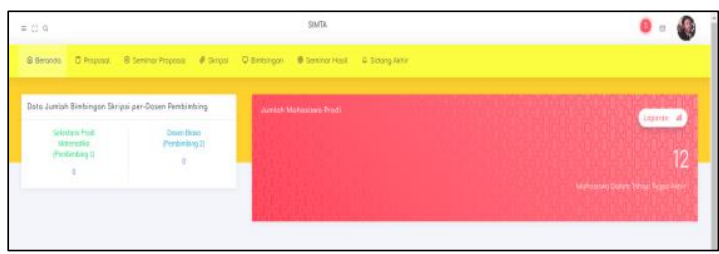

Gbr 8. Antarmuka Dosen (User4)

\section{IV.PENUTUP}

A. Kesimpulan

Berdasarkan pembahasan pada bab sebelumnya kesimpulan dari penelitian ini adalah sebagai berikut :

1. Telah dibuat sistem informasi monitoring tugas akhir berbasis web online yang memiliki fiturfitur sesuai dengan perancangan yang telah dibuat.

2. SIMTA dapat membantu dosen dan fakultas MIPA Universitas Tanjungpura untuk melakukan kontrol atau monitoring mahasiswa yang sedang melakukan tugas akhir, berdasarkan lamanya pengambilan tugas akhir maupun berdasarkan lama studi mahasiswa.

3. Dengan adanya SIMTA, Fakultas MIPA memiliki pangkalan data tugas akhir mahasiswa dan rekam jejak tugas akhir mahasiswa, dan adanya pencatatan digital seminar proposal, seminar hasil, maupun sidang sarjana.

B. Saran

Adapun saran yang dapat diberikan untuk peningkatan sistem informasi tugas akhir yang telah dibuat adalah sebagai berikut :

1. Aplikasi dapat dibuat berbasis mobile (teknologi di android atau ios) untuk memudahkan komunikasi dan kontrol terhadap aktivitas mahasiswa.

2. Perlu adanya fitur pengingat otomatis bagi mahasiswa yang sudah lama tidak bimbingan, atau dengan berbagai kondisi, misalnya 6 bulan atau 1 tahun tidak bimbingan, berbasis notifikasi maupun sms gateway.

\section{REFERENSI}

[1] Daft, R.L., Sormunen, J. and Parks, D. 1988, "Chief executive scanning, environmental characteristics, and company performance: an empirical study", Strategic Management Journal, Vol. 9 No. 2, pp. 123-39.

[2] Hakim, H. A. B. \& Bandono, 2015. OMEKA: Aplikasi Pengelola Arsip Digital dalam berbagai Format. Jupiter, Volume XIV, p. 7.

[3] Indrayani, E. (2011). Pengelolaan Sistem Informasi akademik Perguruan Tinggi Berbasis Teknologi Informasi dan Komunikasi. Jurnal Penelitian Pendidikan, 12.

[4] Kuratko, D., Goodale, J. and Hornsby, J. 2001. "Quality practices for a competitive advantage in smaller firms", Journal of Small Business Management, Vol. 39 No. 4, pp. 293-311.

[5] Prihatanto, R. H., Widada, B. \& S, W. L. Y., 2014. Sistem Monitoring Pembimbingan Tugas Akhir di STMIK Sinar Nusantara Surakarta. TIKomSin, p. 9.

[6] Rafidianto, M. R., Sholiq \& Muqtadiroh, F. A., 2013. Rancang Bangun Perangkat Lunak Sistem Monitoring Tugas Akhir (TA) untuk Pengembangan Sistem

[7] Informasi Terintegrasi sesuai Kebutuhan Pengisian Borang Akreditasi BAN-PT pada Jurusan Sistem Informasi ITS. Pomits, Volume 1, p. 6.

[8] Ramadhan, M. R., Nugroho, L. E. \& Sulistyo, S., 2017. Perancangan Sistem Informasi Monitoring Skripsi. CITEE, p. 6. 
[9] Ramayasa, I. P. \& Arnawa, I. B. K. S., 2015. Perancangan Sistem Monitoring Pengerjaan Skripsi Pada Stmik Stikom Bali Berbasis Web. Bali, Konferensi Nasional Sistem \& Informatika.

[10] Rifauddin, M., 2016. Pengelolaan Arsip Elektronik Berbasis Teknologi. KHIZANAH AL-HIKMAH, Volume 4, p. 11.

[11] Turban, E., Aronson, Jay E., \& Peng - Liang, Ting. (2005). Decision Support Systems and Intelligent System. New Jersey: Pearson Education, Inc.

[12] Turban, E., Aronson, Jay E., \& Peng - Liang, Ting. (2005) Decision Support Systems and Intelligent System. New Jersey: Pearson Education, Inc.

[13] Al-Bahra. (2005). Analisis dan Desain Sistem Informasi. Yogyakarta: Graha Ilmu. 